\title{
ANÁLISE DO DISCURSO RELIGIOSO À LUZ DA ÉTICA MÉDICA: O MINISTÉRIO PÚBLICO DE SANTA CATARINA E A CONSTRUÇÃO DE UMA TEORIA ARGUMENTATIVA
}

\author{
L'ANALYSE DU DISCOURS RELIGIEUX À LA LUMIÈRE DE L'ÉTHIQUE \\ MÉDICALE : LE MINISTÈRE PUBLIC DE SANTA CATARINA ET LA \\ CONSTRUCTION D'UNE THÉORIE DE L'ARGUMENTATION
}

\author{
${ }^{1}$ Carlos Augusto Lima Campos
}

\section{RESUMO}

O artigo se propõe a analisar, a partir dos discursos presentes na Ação Cível no 2011.0895513, de Chapecó/SC, a perspectiva de liberdade, em suas variadas acepções constitucionais, com vistas a identificar princípios colidentes e sua reverberação nos âmbitos público e particular. A abordagem priorizará os discursos encampados pelo Ministério Público do Estado de Santa Catarina, identificando o destacado papel que a argumentação religiosa ocupou em cada uma das esferas de atuação, ressaltando a importância do julgado para situações análogas, mormente no que tange à conduta adotada por profissionais da área da saúde diante da chamada objeção de consciência.

Palavras-chave: Discurso, Liberdades, Objeção de consciência, Princípios, Religião

\section{RESUME}

L'article propose d'analyser, à partir du discours présente dans l'action civile $\mathrm{n}^{\mathrm{o}}$ 2011.0895513, Chapecó/SC, le point de vue de la liberté dans ses différentes significations pour identifier le ciblage constitutionnel se heurtant des principes et leurs répercussions dans les sphères publique et privée. L'approche donnera la priorité au discours étant établi par le Ministère Public de Santa Catarina, identifier le document en surbrillance que l'argument religieux occupés dans chacune des sphères d'activité, en mettant l'accent sur l'importance de juger des situations similaires, en particulier concernant le comportement adopté par les professionnels de la santé avant l'appel d'objection de conscience.

Mots-clés: Discours, Libertés, L’objection de conscience, Principes, Religion

\footnotetext{
${ }^{1}$ Mestre em Ciências da Religião pela Universidade do Estado do Pará, UEP, Belém - PA (Brasil).

E-mail: prof.carloscampos@gmail.com
} 


\section{INTRODUÇÃO}

O artigo se propõe a abordar alguns discursos presentes na Ação Cível nº 2011.0895513, de Chapecó/SC, bem como os aspectos jurídicos afeitos à transfusão de sangue em pacientes Testemunhas de Jeová, sendo importante salientar que dentre os elementos elencados, há de se mencionar - sempre que possível - a postura da Administração Pública, mais especificamente dos médicos que atuam em hospitais públicos, quando se depararem com o problema da objeção de consciência religiosa por religiosos que - não raro - preferem a morte a receberem tratamento que envolva transfusão de sangue, ainda que necessário e indispensável para salvaguardar a própria vida.

O caso concreto diz respeito a expediente do Hospital Regional do Oeste, no município de Chapecó/SC, dando conta da internação de uma jovem de apenas 19 anos de idade, no Centro de Terapia Intensiva (CTI), com quadro de síndrome de angústia respiratória, necessitando receber ventilação mecânica, assim como de procedimento de biópsia do pulmão, sendo ainda provável - à época (ano de 2011) - a necessidade de transfusão de sangue, já que a paciente estava classificada como "gravemente enferma", em virtude de um acidente que culminou na realização de um procedimento de cirurgia cesariana, e cuja criança recém-nascida não conseguia receber cuidados essenciais ao seu pleno desenvolvimento em virtude da crença religiosa de seus pais, fazendo de uma situação inicialmente particular, uma questão de ordem pública, mormente por envolver instituições que possuem legitimidade para intervir em situações como a objeto da investigação em comento.

Os médicos do hospital estadual acima referido suscitaram dúvida acerca do procedimento a ser adotado, do ponto de vista jurídico, uma vez que a paciente apresentou ao hospital - por intermédio de seu marido, então líder do "Salão das Testemunhas de Jeová de Chapecó e Região" - documento padronizado, com algumas partes digitadas e outras preenchidas à mão, por ela assinado juntamente com duas testemunhas, se declarando Testemunha de Jeová e que, mesmo se estivesse correndo perigo de morte, não desejaria receber transfusão de sangue. Na oportunidade, "autorizaria" toda e qualquer decisão sustentada por seu marido, relativa ao estado clínico de deu filho.

Ante a posição técnica adotada pela comunidade médica, contrária à postura encampada pelo grupo religioso em destaque, mais especificamente pela obrigatoriedade de realização de exames na criança, bem como a transfusão de sangue na paciente adulta, que estava correndo 
risco de morte, independentemente de crença religiosa, são colocados em polos colidentes dois valores constitucionais: o direito à crença religiosa e o exercício de seus fundamentos e o dever do Estado de garantir a intangibilidade e a inviolabilidade do direito à vida humana. Eis o problema a ser enfrentado na presente pesquisa.

\section{A AÇÃo}

O Ministério Público do Estado de Santa Catarina, por intermédio da Promotora de Justiça Dra. Vânia Augusta Cella Piazza, propôs representação objetivando apurar infrações às normas de proteção à criança e ao adolescente, cumulada com medida de proteção em desfavor dos pais biológicos, alegando que:

a) conforme informações encaminhadas pelo Conselho Tutelar de Planalto Alegre/SC (distante cerca de $25 \mathrm{~km}$ de Chapecó), os réus não vinham cumprindo com os seus deveres inerentes ao poder familiar, negando a realização de exames pré-natal e, mesmo após o nascimento (prematuro) do filho, furtaram-se a ministrar vacinas necessárias ao regular desenvolvimento da criança;

b) ainda, o conselho tutelar afirma que, num primeiro momento, os genitores da criança se negaram a realizar o teste do pezinho, contudo, após muita insistência, o exame foi feito, assim como o da orelhinha, sendo que neste último o resultado foi negativo;

c) o teste da orelhinha deveria ser refeito em Chapecó, no entanto, o genitor do menor não permitiu que levassem a criança àquela cidade, tampouco permitiu que fossem ministradas as vacinas, alegando que a sua religião não admite tais procedimentos;

d) após serem notificados, os réus compareceram à Promotoria de Justiça da Infância e Juventude e, mesmo depois de serem advertidos, mantiveram seu posicionamento;

e) tal conduta negligente coloca em risco a saúde e a vida do filho recém-nascido;

f) não se contesta acerca da liberdade religiosa, mas o direito à vida é pressuposto material do exercício dos demais direitos, de maneira que o direito à vida da criança sobrepõe- se ao direito à liberdade religiosa dos pais;

g) os pais estão expondo o filho ao perigo da doença, sendo tal conduta uma forma de violência. 
Requereu, o membro do Ministério Público, a procedência do pedido para que fosse aplicada a medida de proteção prevista no art. 101, $\mathrm{V}^{1}$, do Estatuto da Criança e do Adolescente, materializado no encaminhamento do menor para a realização do teste da orelhinha e das vacinas necessárias, suprindo a ordem judicial, o não consentimento dos pais. A Promotora juntou o relatório formulado pelo Conselho Tutelar de Planalto Alegre, bem como documentação relativa à religião dos réus.

\section{A CONTESTAÇÃo}

Os réus, por intermédio da Ordem dos Advogados do Brasil (Subseção Chapecó/SC), aduziram que:

a) a mãe biológica realizou todos os exames de pré-natal na unidade de saúde de sua cidade;

b) a única restrição quanto aos exames do filho menor diz respeito às vacinas, procedimento este não obrigatório e que não teria o condão de garantir o direito à vida;

c) a simples alegação de que a vacinação tem o aval da ciência não garantiria sua eficácia plena, ressaltando que o organismo humano tem seus próprios mecanismos de defesa, suficientemente capazes de combater grande parte das viroses espalhadas pelo mundo;

d) a vacina retira do organismo o incentivo de produzir autodefesa, aumentando o surgimento de outros tipos de doenças;

e) além de uma questão religiosa, a negativa da vacina trata de uma questão de saúde, proteção à criança e não configura negligência;

f) a população indígena não leva suas mulheres para realizarem o pré-natal, tampouco ministram vacinas em seus filhos, e nem por isso tem o comportamento rotulado como sendo "negligente";

g) a religião dos réus apregoa que além de fazer mal à saúde, a vacinação impede o acesso a uma espécie de "plano astral";

h) o Movimento Testemunha de Jeová do Brasil luta para elevar o nível espiritual, moral, físico e intelectual da comunidade em geral, e atua em defesa e proteção da família;

i) o princípio do direito à vida e do direito à liberdade religiosa não estão em confronto, pois não se trata de um tratamento de saúde em que a não submissão possa acarretar perda de uma vida.

\footnotetext{
1 Art. 101, V, do ECA: "Verificada qualquer das hipóteses previstas no art. 98, a autoridade competente poderá determinar, dentre outras, as seguintes medidas: (...) requisição de tratamento médico, psicológico ou psiquiátrico, em regime hospitalar ou ambulatorial”".

2 Art. 98, do ECA: As medidas de proteção à criança e ao adolescente são aplicáveis sempre que os direitos reconhecidos nesta Lei forem ameaçados ou violados: I - por ação ou omissão da sociedade ou do Estado; II - por falta, omissão ou abuso dos pais ou responsável; III - em razão de sua conduta.
} 


\section{A SENTENÇA}

Ao proferir seu julgamento, a Juíza de Direito, Dra. Angélica Fassini, julgou parcialmente procedente o pedido formulado na petição inicial para que, com fulcro nos artigos 98², II, e 101, V, do Estatuto da Criança e do Adolescente, fosse aplicado a medida de proteção à criança em questão, consistente na realização de exames, vacinas e acompanhamentos médicos, de acordo com a prescrição de profissional de medicina legalmente habilitado ou programas estatais. Caso houvesse recusa dos pais em levarem o menor aos atendimentos previamente agendados pela Secretaria de Saúde Pública do Município em que residem ou causarem qualquer obstáculo aos procedimentos médicos, deveriam pagar multa diária no valor de R \$ 100,00 (cem reais), além de eventualmente responderem civil e criminalmente pela conduta, não se afastando possível ação objetivando suspensão ou até mesmo a perda do poder familiar.

\section{A APELAÇÃO}

Inconformados, os pais biológicos apelaram alegando, em resumo, que:

a) não se está diante de um tratamento de saúde em que a criança corre risco de vida caso não seja adotado o procedimento;

b) as vacinas não garantem o direito à vida do menor;

c) muito embora a vacinação tenha o aval da ciência, não há como comprovar $100 \%$ (cem por cento) a sua eficácia;

d) vacinas não são tratamentos de saúde e sim métodos preventivos;

e) o corpo humano tem seus próprios mecanismos de defesa capazes de combater grande parte de todas as viroses espalhadas pelo mundo e a vacinação retira do organismo o incentivo de produzir essa autodefesa, além de, em alguns casos, aumentarem a incidência do surgimento de outros tipos de doença;

f) o direito à liberdade religiosa exercido pelos apelantes em nada afronta o direito à vida da criança;

g) é direito do cidadão escolher a doutrina religiosa que pretende seguir e esses ensinamentos e regras se estendem aos filhos; 
h) a liberdade religiosa está garantida na Constituição Federal de 1988 (art. 5º, VI e $\mathrm{XLI})^{3}$, sendo que as normas infraconstitucionais contrárias aos princípios constitucionais são inválidas, ainda que sejam normas de proteção estabelecidas no Estatuto da Criança e do Adolescente;

i) inúmeros estudos afirmam que a vacinação pode causar malefícios e, em muitos casos, a morte de pacientes, ao invés de promover saúde.

\section{O PROCURADOR GERAL DE JUSTIÇA}

O Procurador de Justiça, Dr. Tycho Brahe Fernandes, manifestou-se pelo conhecimento e não provimento do recurso, requerendo a concessão da antecipação dos efeitos da tutela, concedida em sentença, no sentido de aplicar a medida de proteção à criança, submetendo-a à vacinação recomendada para a sua idade, alertando os apelantes de que o descumprimento da ordem judicial poderia causar a destituição do poder familiar.

Considerou, a autoridade máxima do Ministério Público do Estado de Santa Catarina, incontroverso que os apelantes proíbem a vacinação do menor em prol de sua crença religiosa, alegando que a ausência de vacina no organismo da criança não causa dano à sua saúde, uma vez que tal medicamento é utilizado apenas como método de prevenção.

\footnotetext{
3 Art. $5^{\circ}$ Todos são iguais perante a lei, sem distinção de qualquer natureza, garantindo-se aos brasileiros e aos estrangeiros residentes no País a inviolabilidade do direito à vida, à liberdade, à igualdade, à segurança e à propriedade, nos termos seguintes:

(...)

VI - é inviolável a liberdade de consciência e de crença, sendo assegurado o livre exercício dos cultos religiosos e garantida, na forma da lei, a proteção aos locais de culto e a suas liturgias;

(...)

XLI - a lei punirá qualquer discriminação atentatória dos direitos e liberdades fundamentais;

4 Art. 5º, VIII, da CRFB/1988: Todos são iguais perante a lei, sem distinção de qualquer natureza, garantindo-se aos brasileiros e aos estrangeiros residentes no País a inviolabilidade do direito à vida, à liberdade, à igualdade, à segurança e à propriedade, nos termos seguintes: (...) VIII - ninguém será privado de direitos por motivo de crença religiosa ou de convicção filosófica ou política, salvo se as invocar para eximir-se de obrigação legal a todos imposta e recusar-se a cumprir prestação alternativa, fixada em lei;
} 
Muito embora seja garantido constitucionalmente a liberdade religiosa aos brasileiros (art. 5 , VI e VIII ${ }^{4}$, da Constituição Federal/1988), considerou inadmissível sobrepô-la ao bem maior da vida e da saúde de uma criança com menos de 1 ano de idade, que sequer tinha discernimento para optar acerca de uma crença religiosa.

Conforme bem exposto pelo Procurador de Justiça Dr. Tycho Brahe Fernandes, no presente caso, obviamente que o menor ainda não apresentava condições de formar convicção por qualquer segmento religioso, de modo que não poderia sofrer as privações estabelecidas pela crença dos pais, especialmente quando estas puderem violar algum de seus direitos fundamentais, como é o caso da saúde e da vida (artigos 6º 196 e 227 da CRFB/1988) ${ }^{5}$. Isso porque o direito à vida, uma vida saudável, de crianças que ignoram as ideologias religiosas de seus pais, está acima do direito desses de exercer uma religião que ignora aqueles direitos.

\footnotetext{
5 Art. 6º da CRFB/1988: São direitos sociais a educação, a saúde, a alimentação, o trabalho, a moradia, o transporte, o lazer, a segurança, a previdência social, a proteção à maternidade e à infância, a assistência aos desamparados, na forma desta Constituição.

Art. 196, da CRFB/1988: A saúde é direito de todos e dever do Estado, garantido mediante políticas sociais e econômicas que visem à redução do risco de doença e de outros agravos e ao acesso universal e igualitário às ações e serviços para sua promoção, proteção e recuperação.

Art. 227, da CRFB/1988: Art. 227. É dever da família, da sociedade e do Estado assegurar à criança, ao adolescente e ao jovem, com absoluta prioridade, o direito à vida, à saúde, à alimentação, à educação, ao lazer, à profissionalização, à cultura, à dignidade, ao respeito, à liberdade e à convivência familiar e comunitária, além de colocá-los a salvo de toda forma de negligência, discriminação, exploração, violência, crueldade e opressão.

$\S 1^{\circ} \mathrm{O}$ Estado promoverá programas de assistência integral à saúde da criança, do adolescente e do jovem, admitida a participação de entidades não governamentais, mediante políticas específicas e obedecendo aos seguintes preceitos:

I - aplicação de percentual dos recursos públicos destinados à saúde na assistência materno-infantil;

II - criação de programas de prevenção e atendimento especializado para as pessoas portadoras de deficiência física, sensorial ou mental, bem como de integração social do adolescente e do jovem portador de deficiência, mediante o treinamento para o trabalho e a convi vência, e a facilitação do acesso aos bens e serviços coletivos, com a eliminação de obstáculos arquitetônicos e de todas as formas de discriminação.

$\S 2^{\circ}$ A lei disporá sobre normas de construção dos logradouros e dos edifícios de uso público e de fabricação de veículos de transporte coletivo, a fim de garantir acesso adequado às pessoas portadoras de deficiência.

$\S 3^{\circ} \mathrm{O}$ direito a proteção especial abrangerá os seguintes aspectos:

I - idade mínima de quatorze anos para admissão ao trabalho, observado o disposto no art.

$7^{\circ}$, XXXIII; II - garantia de direitos previdenciários e trabalhistas;

III - garantia de acesso do trabalhador adolescente e jovem à escola;

IV - garantia de pleno e formal conhecimento da atribuição de ato infracional, igualdade na relação processual e defesa técnica por profissional habilitado, segundo dispuser a legislação tutelar específica;

$\mathrm{V}$ - obediência aos princípios de brevidade, excepcionalidade e respeito à condição peculiar de pessoa em desenvolvimento, quando da aplicação de qualquer medida privativa da liberdade;

VI - estímulo do Poder Público, através de assistência jurídica, incentivos fiscais e subsídios, nos termos da lei, ao acolhimento, sob a forma de guarda, de criança ou adolescente órfão ou abandonado;

VII - programas de prevenção e atendimento especializado à criança, ao adolescente e ao jovem dependente de entorpecentes e drogas afins.

$\S 4^{\circ}$ A lei punirá severamente o abuso, a violência e a exploração sexual da criança e do adolescente.

$\S 5^{\circ}$ A adoção será assistida pelo Poder Público, na forma da lei, que estabelecerá casos e condições de sua efetivação por parte de estrangeiros.

$\S 6^{\circ}$ Os filhos, havidos ou não da relação do casamento, ou por adoção, terão os mesmos direitos e qualificações, proibidas quaisquer designações discriminatórias relativas à filiação.

$\S 7^{\circ}$ No atendimento dos direitos da criança e do adolescente levar-se- á em consideração o disposto no art. 204.

$\S 8^{\circ}$ A lei estabelecerá:

I - o estatuto da juventude, destinado a regular os direitos dos jovens;

II - o plano nacional de juventude, de duração decenal, visando à articulação das várias esferas do poder público para a execução de políticas públicas.
} 
Com efeito, muito embora os apelantes tenham, como pais, o pleno direito de educar seus filhos conforme a religião que escolheram, não poderiam privar os menores de seus direitos constitucionalmente garantidos. Do mesmo modo, foi garantido aos apelantes o direito de organizar sua família, desde que não expusessem algum membro a riscos intoleráveis pela sociedade, como é o caso. Os argumentos deduzidos pelos apelantes demonstraram, na ótica do Ministério Público, que eles, ao invocarem seu direito ao livre exercício da religião, estariam mais preocupados com seus próprios direitos de segunda geração, do que com o exercício dos direitos de primeira geração de seus filhos. $\mathrm{O}$ direito de exercer uma religião não está acima, nem próximo, do direito à vida, em especial, repita-se, quando se está discutindo o direito de um pai expor a vida de seu filho a graves riscos em razão de seus dogmas religiosos.

Asseverou ser direito de toda criança no Brasil ser vacinada, gratuitamente, sendo obrigação dos pais fazer com que esse direito seja exercido, sob pena de intervenção do Estado na Família, como ocorre no caso em análise.

Esclareceu que os aspectos religiosos são importantes para o crescimento e formação do indivíduo, devendo ser respeitado o posicionamento de cada um e as consequências que apresentam no âmbito familiar. Contudo, considerou necessária uma atuação cautelosa para que a garantia da livre manifestação do pensamento religioso não fosse utilizada de forma impensada, ausente de proporcionalidade e razoabilidade, especialmente quando confrontada com outros princípios constitucionais.

Diante disso, o Ministério Público considerou adequada a sentença proferida pela Juíza de Direito Angélica Fassini, por encontrar fundamentos precisos, coerentes e esclarecedores para a emblemática em comento.

Considerou que os elementos presentes nos autos comprovam que o filho dos réus não recebeu as vacinas prescritas para sua idade e que isso decorreu da negativa dos pais, alicerçada, basicamente, na alegação de que sua crença religiosa não permite essa prática e por duvidarem da eficácia dos medicamentos, temendo consequências prejudiciais à saúde do menor. Outrossim, destaca que os demais aspectos probatórios convencem de que a criança goza de boa saúde e, a despeito da já referida relutância, os pais não se omitem em prover os cuidados e necessidades de nenhum de seus filhos.

Fica evidenciado, tanto no discurso da Magistrada quanto nos dos membros do Ministério Público, que a liberdade religiosa constitui cláusula pétrea constitucional (art. $5^{\circ}$, VIII, dentre outros), constituindo um dos alicerces do Estado Democrático de Direito e 
referencial de sentido existencial para aqueles que a exercem, de acordo com as variações doutrinárias de cada religião.

E para garantir essa liberdade, o Estado (brasileiro) é considerado laico, de modo que, ao mesmo tempo em que garante a possibilidade da existência de diversas religiões, não assume partido de uma ou de outra em sua atuação. Entrementes, é

\begin{abstract}
(...) importante ressaltar que em nosso país neutralidade estatal não se confunde com indiferença. (...) O que não se admite é que o Estado assuma determinada concepção religiosa como a oficial ou a correta, que beneficie um grupo religioso em detrimento dos demais ou conceda privilégios. O que se deve promover é a livre competição no "mercado de ideias religiosas" (STF. STA 389 AgR. Relator(a): Min. Gilmar Mendes (Presidente), Tribunal Pleno. Julgado em: 03/12/2009).
\end{abstract}

Destarte, ao lado do aspecto "negativo" relativo à liberdade religiosa, existe um "positivo", que consiste em o Estado garantir o seu exercício, até mesmo entre particulares. No entanto, cumpre saber em que momento a pessoa passa a exercer essa liberdade. Este parece ser o ponto nodal do caso em apreço.

Não se pode deixar de reconhecer que os aspectos religiosos são inerentes à educação prestada aos filhos e isso implica permitir que os pais busquem repassar a vida religiosa por eles seguida. Por isso, apresenta-se constitucionalmente defensável garantir que os pais tentem transmitir os valores que julguem corretos aos seus descendentes, porque isso faz parte da própria entidade familiar.

No entanto, isso não pode ocorrer de forma descontrolada e deve sofrer certa influência do Estado para evitar abusos, sempre tendo em vista a necessidade de promover a proteção integral de seres humanos de tamanha vulnerabilidade. $\mathrm{O}$ que interessa resguardar não são as expectativas que os pais nutrem em relação aos filhos, mas a integridade destes.

Também não parece ser constitucionalmente adequado que a religião professada pelos pais possa ser invocada em nome do filho que ainda não possui capacidade para exercitar tal liberdade. Aliás, isso seria uma contradição, pois implicaria imposição religiosa e fulminaria esse direito fundamental, que é individual.

Isso ganha maior sustentação quando o exercício da doutrina religiosa escolhida pelos pais puder, de alguma forma, prejudicar a criança, como é o caso de deixar de receber as vacinas destinadas a prevenir patologias presentes ou futuras. Como poderia ser legítimo impor esse ônus (de possível prejuízo à saúde) se nem ao menos lhe foi possível ainda exprimir sua orientação religiosa? 
A liberdade religiosa consiste também em permitir que a pessoa proceda a escolha de acordo com suas próprias convicções. Este ato de vontade deve ser construído ao longo do tempo e requer algum entendimento para que possa ocorrer. Obviamente que uma criança em tenra idade ainda não exercita religião alguma e muito menos tem discernimento para optar por esta, aquela ou nenhuma crença.

Caso fosse admitida a recusa dos réus, estar-se-ia assegurando que o filho sofresse os “ônus" religiosos sem que os tivesse acolhido voluntariamente, isto é, sem que ainda seriamente tenha feito sua escolha. Em outras palavras: os pais usam sua religião como se fosse, a priori, a do filho.

Conquanto o círculo familiar e de convivência ocasione, direta ou indiretamente, essa escolha paulatina, que implicaria inclusive mudança ou abdicação total ou parcial de religiões, não parece constitucionalmente correto conceber que a religião dos pais necessariamente deve ser seguida pelos filhos (sendo a recíproca também verdadeira). Tal não mais seria que imposição autoritária, fazendo sucumbir a liberdade de escolha da pessoa que está criando condições mentais e biológicas para exercê-la.

Se ao Estado não cabe exigir que as pessoas sigam uma religião, aos particulares também descabe assim proceder. O que se permite é a prestação de orientações para que a escolha seja realizada. Jamais a sua supressão.

Esse direito fundamental também merece proteção nas relações existentes entre os particulares (eficácia horizontal dos direitos fundamentais), mesmo que se verifique entre pais e filhos, sob pena de permitir certo autoritarismo nas relações privadas.

A própria Constituição Federal (art. 226, § 8 ) $^{6}$ preconiza que o Estado “(...) assegurará a assistência à família na pessoa de cada um dos que a integram, criando mecanismos para coibir a violência no âmbito de suas relações".

\footnotetext{
6 Art. 226. A família, base da sociedade, tem especial proteção do Estado.

$\S 1^{\circ} \mathrm{O}$ casamento é civil e gratuita a celebração.

$\S 2^{\circ} \mathrm{O}$ casamento religioso tem efeito civil, nos termos da lei.

$\S 3^{\circ}$ Para efeito da proteção do Estado, é reconhecida a união estável entre o homem e a mulher como entidade familiar, devendo a lei facilitar sua conversão em casamento.

$\S 4^{\circ}$ Entende-se, também, como entidade familiar a comunidade formada por qualquer dos pais e seus descendentes.

$\S 5^{\circ}$ Os direitos e deveres referentes à sociedade conjugal são exercidos igualmente pelo homem e pela mulher.

$\S 6^{\circ} \mathrm{O}$ casamento civil pode ser dissolvido pelo divórcio.

$\S 7^{\circ}$ Fundado nos princípios da dignidade da pessoa humana e da paternidade responsável, o planejamento familiar é livre dec isão do casal, competindo ao Estado propiciar recursos educacionais e científicos para o exercício desse direito, vedada qualquer forma coercitiva por parte de instituições oficiais ou privadas.

$\S 8^{\circ} \mathrm{O}$ Estado assegurará a assistência à família na pessoa de cada um dos que a integram, criando mecanismos para coibir a violência no âmbito de suas relações.
} 
O Procurador Geral de Justiça traz à lume o dever de proteção imposto ao Estado (mormente ao Judiciário) no que toca aos direitos fundamentais nas relações entre particulares, como aquelas existentes no núcleo familiar, alicerçado no princípio constitucional implícito da máxima efetividade dos direitos fundamentais.

Reitera que crianças de tenra idade ainda não exercitam sua liberdade (de escolha) religiosa, de modo que não devem sofrer as respectivas privações estabelecidas quando isso puder acarretar alguma espécie de violação aos seus direitos fundamentais (como a saúde).

Diferente é uma pessoa adulta, com plena consciência de suas escolhas, e que aceita os ditames religiosos ainda que lhe causem certo sacrifício (não demasiado, pois o Direito não pode ser conivente com atos que ocasionem a abdicação da própria dignidade, como adiante será abordado quando da análise da situação clínica em que a mãe da criança se encontrava, quando de sua hospitalização no Hospital Regional do Oeste, no município de Chapecó/SC).

$\mathrm{O}$ fator determinante, portanto, é respeitar a escolha religiosa feita pela pessoa, que em se tratando de criança de pouca idade, está longe de ser feita.

Isso os réus não estavam fazendo, porque, desde logo, buscaram aplicar ao filho as restrições da religião que seguem e que podem lhe causar algum dano à saúde, sem ao menos aguardar a manifestação da criança. O que objetivaram foi resguardar os seus ditames religiosos, e não os da criança, que ainda sequer optara por trilhar o mesmo caminho.

Por conta disso, se de um lado existe o interesse dos pais, de outro também há o do Estado e da Sociedade, já que é dever constitucional de todos promover a proteção das crianças e adolescentes, como bem dispõe o artigo 227, da CRFB/1988:

\footnotetext{
Art. 227. É dever da família, da sociedade e do Estado assegurar à criança, ao adolescente e ao jovem, com absoluta prioridade, o direito à vida, à saúde, à alimentação, à educação, ao lazer, à profissionalização, à cultura, à dignidade, ao respeito, à liberdade e à convivência familiar e comunitária, além de colocá-los a salvo de toda forma de negligência, discriminação, exploração, violência, crueldade e opressão.
}

Em suma: os pais possuem o direito de buscar repassar sua crença religiosa aos filhos, mas até o ponto que isso não lhes possa acarretar consequências prejudiciais ou sacrifícios que ainda não podem ser escolhidos pelos menores.

Ao mencionarem que não existe comprovação de eficácia absoluta das vacinas aplicadas, não incorrem em equívoco, porquanto nada é absoluto na ciência. Porém, existe larga aceitação científica do uso de determinados medicamentos como métodos preventivos de doenças 
perigosas. Tanto é assim que não são poucas as campanhas patrocinadas pelo Estado no que diz respeito não só às crianças, como também aos adultos e idosos.

A saúde é direito fundamental que deve ser atendido pelo Estado, promovendo programas de assistência integral em favor das crianças (art. 227, § $1^{\circ}$, da CRFB/1988). Isto inclui exames e vacinas realizadas nos primeiros anos de vida, disponibilizados gratuitamente pela rede pública de saúde para o único fim de promover o desenvolvimento sadio dos infantes e manter a população à salvo de doenças infectocontagiosas.

Com isso, não se almeja somente proteger a saúde da pessoa submetida ao tratamento, mas também de todas as outras, existindo inexorável interesse coletivo na erradicação de doenças.

Fato recente demonstrou a importância das vacinas para evitar a proliferação descontrolada de patologias. O vírus mortal da "Gripe A" (também chamada de "Gripe Suína", uma variação da gripe comum causada pelo vírus Influenza H1N1), que se proliferou em escala global em pouco tempo e vitimou milhares de pessoas, apenas foi contido graças às vacinas de anticorpos. Não fosse esse tratamento, milhões de vidas poderiam ter sido dizimadas e a saúde pública (em nível global) estaria em estado periclitante.

Os réus não lograram êxito em demonstrar a ineficácia ou riscos inaceitáveis das vacinas aplicadas às crianças, não desconstituindo os fatos de conhecimento notório que indicam o contrário.

Face a isso, a recusa dos pais em submeter o filho às vacinas prescritas sucumbe diante do fundamental direito ao desenvolvimento sadio deste e, bem assim, para inibir riscos à coletividade.

O Ministério Público discorreu acerca da impossibilidade da aplicação de sanções administrativas aos réus, em nítida referência aos artigos $245^{7}$ e seguintes do Estatuto da

\footnotetext{
7 Art. 245, do ECA: Deixar o médico, professor ou responsável por estabelecimento de atenção à saúde e de ensino fundamental, pré-escola ou creche, de comunicar à autoridade competente os casos de que tenha conhecimento, envolvendo suspeita ou confirmação de maus-tratos contra criança ou adolescente:

Pena - multa de três a vinte salários de referência, aplicando-se o dobro em caso de reincidência.
} 
Criança e do Adolescente, que preconizam infrações administrativas, cominando as respectivas sanções aos seus violadores. Ponderou apresentar-se indubitável que somente haveria responsabilização quando restasse caracterizado dolo ou culpa do agente infrator, além do respectivo nexo de causalidade.

No caso em apreço, a conduta descrita na peça inaugural, em tese, subsume-se formalmente à infração administrativa estatuída no artigo 249, do Estatuto da Criança e do Adolescente, que assim preconiza:

Art. 249. Descumprir, dolosa ou culposamente, os deveres inerentes ao poder familiar ou decorrente de tutela ou guarda, bem assim determinação da autoridade judiciária ou Conselho Tutelar: Pena - multa de três a vinte salários de referência, aplicando-se o dobro em caso de reincidência.

Conforme evidenciado, para vislumbrar a ocorrência da mencionada infração, é necessário que se constate a inobservância, além de determinação judicial ou do Conselho Tutelar, dos deveres atinentes à tutela, guarda ou ao poder familiar.

Estes, por seu turno, estão descritos, ainda que não de forma exaustiva, no artigo 22, da Lei 8.069/90 (ECA):

Art. 22. Aos pais incumbe o dever de sustento, guarda e educação dos filhos menores, cabendo-lhes ainda, no interesse destes, a obrigação de cumprir e fazer cumprir as determinações judiciais.

Entretanto, a recusa dos réus em vacinar o filho apresentou-se, em seu íntimo, como legítima e não houve qualquer lesividade decorrente dessa conduta, sendo irrelevante para justificar maior intervenção estatal.

Ressalte-se que, apesar da omissão dos pais, a criança está bem cuidada e apresenta ótima saúde, de tal modo que seria totalmente desproporcional aplicar qualquer sanção aos réus, pois agiram segundo sua crença religiosa e não por desleixo ou desinteresse, de maneira que a mencionada medida de proteção foi considerada, pela justiça catarinense, como suficiente para resguardar os direitos da criança, apresentando-se redundante a aplicação de qualquer sanção, ainda que extrapenal. 


\section{ESTADO LAICO, LIBERDADE DE CRENÇA E OS TESTEMUNHAS DE JEOVÁ}

A emblemática relativa à questão da liberdade religiosa e à vida digna de crianças $e$ adolescentes poderia encerrar a proposta da presente investigação. Contudo, há outra personagem no enredo, capaz de contribuir ricamente para a discussão afeita às perspectivas de Direito, Religião e Espaço Público no Brasil, mormente a partir da hermenêutica neoconstitucionalista. Trata-se da mãe da criança objeto da Apelação Cível no 2011.089551-3, de Chapecó/SC.

Conforme conhecimento convencional, o Brasil adotou posição constitucional pela laicidade do Estado. Isto quer dizer que todos os cidadãos são livres para escolher a religião que melhor convier à sua consciência e crença (artigo $5^{\circ}$, inciso VI, da $\mathrm{CRFB} / 88^{8}$ ), ou ainda não adotar credo algum. De outro lado, não é possível aos entes federativos adotar religião oficial e, tampouco, fomentar religiões ou opor empecilhos e dificuldades ao livre exercício pelos estabelecimentos religiosos, devotos e seguidores (artigo 19, I, da CRFB/88 ${ }^{9}$ ). Sem dúvidas, a laicidade estatal e o princípio democrático proporcionaram - e proporcionam - o surgimento e a difusão de diversas espécies de religião e crenças no Brasil.

As Testemunhas de Jeová trazem consigo, como princípio religioso, decorrente de interpretação de passagens bíblicas, a impossibilidade de realização de tratamentos médicos que importem em transfusão de sangue, mesmo que em risco esteja a vida do paciente.

Pergunta importante para se tentar solucionar o problema consiste em saber se é aceitável, do ponto de vista constitucional, que alguém, sob o fundamento de professar crença religiosa, dentro de um hospital (público ou privado), pode impedir o médico de cumprir com sua histórica missão de salvar vidas, valendo-se dos instrumentos, técnicas e tratamentos que a ciência médica lhe oportuniza. E mais: seria aceitável que o médico (sobretudo o servidor público) se exponha a ser responsabilizado administrativa, civil e penalmente caso venha a atender à manifestação de vontade do paciente, que recusa tratamento clínico em detrimento de sua crença religiosa?

\footnotetext{
8 “Art. $5^{\circ}(\ldots)$ - VI - é inviolável a liberdade de consciência e de crença, sendo assegurado o livre exercício dos cultos religiosos e garantida, nam forma da lei, a proteção aos locais de culto e a suas liturgias".

9 “Art. 19. É vedado à União, aos Estados, ao Distrito Federal e aos Municípios: I - estabelecer cultos religiosos ou igrejas, subvencioná-los, embaraçar-lhes o funcionamento ou manter com eles ou seus representantes relações de dependência ou aliança, ressalvada, na forma da lei, a colaboração de interesse público
} 
Há fundamentos jurídicos sólidos e importantes, adotados por parte da doutrina brasileira e da jurisprudência, no sentido de que os médicos devem respeitar a crença professada pelas Testemunhas de Jeová, merecendo destaque os seguintes argumentos: (1) o direito do cidadão de professar crença religiosa, ainda que as opções por ele externadas, a despeito de seguir o dogma religioso que adota, ponham em risco a sua vida; (2) o direito do cidadão de dispor do próprio corpo, como manifestação do princípio da privacidade; (3) o direito do cidadão de recusar tratamento médico, com fundamento em crença religiosa e também no princípio da autonomia da vontade, o que, à luz da CRFB/1988, permite ao cidadão (paciente) o exercício de objeções de consciência; e (4) o princípio da dignidade humana, que exige seja o homem/cidadão concebido não como um instrumento do direito, mas um fim em si mesmo, destinatário dos direitos fundamentais encartados na CRFB/1988, dentre eles o de professar crença religiosa que impeça a continuidade da vida humana caso alguma medida clínica ou médica contrarie seus fundamentos religiosos.

\section{REGULAMENTAÇÃO JURÍDICA DA TRANSFUSÃO DE AUTONOMIA DA VONTADE}

Importante registrar que não há norma legal e constitucional que expressamente regule o problema da obrigatoriedade da transfusão de sangue no Brasil. Outrossim, registre-se que está tramitando na Câmara dos Deputados o Projeto de Lei (PL) n ${ }^{\circ} 6.335 / 2009$, de autoria do Deputado Federal Gonzaga Patriota, que se propõe a regulamentar o "direito à objeção de consciência”, mas que, em nenhum momento, discute o dever do médico de não ministrar tratamento clínico a paciente por conta de suas convicções religiosas, sobretudo quando estiver em iminente risco de morte.

O Estado do Rio de Janeiro, por exemplo, por intermédio da Lei Estadual nº. 3.613, de 18 de julho de 2001 (que regulamentou o artigo 287, da Constituição Estadual de 1989), dispôs sobre os direitos dos usuários dos serviços de saúde e, no artigo $2^{\circ}$, inciso VII ${ }^{10}$, estabeleceu ser direito do usuário ter ciência clara e precisa dos procedimentos e tratamentos a que será submetido, para possibilitar-lhe o consentimento ou a recusa. A regra não inova no ordenamento jurídico, vez que repete, conforme será explorado, o que contém o artigo 15, do Código Civil Brasileiro, e em nenhum momento faculta ao cidadão dispor da própria vida, quando em iminente perigo, em hospital público, por razões de ordem religiosa.

\footnotetext{
${ }^{10}$ Art. $2^{\text {o }}$ - São direitos dos usuários dos serviços de saúde no Estado do Rio de Janeiro: VII - consentir ou recusar, de forma livre, voluntária e esclarecida, com adequada informação, procedimentos diagnósticos ou terapêuticos a serem realizados;
} 
Importante registrar que a Lei Estadual 3.613/2001, de forma bastante polêmica, parece permitir, no artigo $2^{\circ}$, inciso XXIII, a prática da distanásia, quando estabelece ser direito do cidadão "recusar tratamentos dolorosos ou extraordinários para tentar prolongar a vida". A distanásia, assevere-se, diferencia-se sobremaneira da questão tratada neste trabalho, na medida em que não se propõe a salvar a vida do doente, que está em iminente perigo, mas sim o seu mero prolongamento com remédios e terapias dolorosas, que apenas trarão mais sofrimento para o paciente e o farão morrer lentamente.

Enfatize-se, assim, que não há norma legal que permita, expressamente, a objeção ao recebimento de transfusão de sangue com fundamento em crença religiosa. Todavia, o Conselho Federal de Medicina (CFM) editou a Resolução CFM nº 1.021/80, e estabeleceu que os médicos do Brasil, públicos ou privados, devem, em caso de risco de morte do paciente, não sendo possível qualquer outra técnica alternativa, proceder à transfusão de sangue.

O Conselho Regional de Medicina do Estado do Rio de Janeiro - CREMERJ, reiterando a normatização traçada pelo CFM, editou a RESOLUÇÃO CREMERJ nº 136/1999 para regular a matéria controvertida objeto deste estudo. Confiram-se os artigos $1^{\circ}$ e $3^{\circ}$ :

\begin{abstract}
Art. $1^{\circ} \mathrm{O}$ médico, ciente formalmente da recusa do paciente em receber transfusão de sangue e/ou seus derivados, deverá recorrer a todos os métodos alternativos de tratamento ao seu alcance.

Art. $3^{\circ}$ - O médico, verificando a existência de risco de vida para o paciente, em qualquer circunstância, deverá fazer uso de todos os meios ao seu alcance para garantir a saúde do mesmo, inclusive efetuando a transfusão de sangue e/ ou seus derivados, comunicando, se necessário, à Autoridade Policial competente sobre sua decisão, caso os recursos utilizados sejam contrários ao desejo do paciente ou de seus familiares.
\end{abstract}

O Código de Ética Médica, instituído por meio da Resolução CFM nº 1.246/88, de 08 de janeiro de 1988, publicada no D.O.U de 26 de janeiro do mesmo ano, por sua vez, estabelece:

É vedado ao médico:

Art. 46 - Efetuar qualquer procedimento médico sem o esclarecimento e o consentimento prévios do paciente ou de seu responsável legal, salvo em iminente perigo de vida.

Art. 56: Desrespeitar o direito do paciente de decidir livremente sobre a execução de práticas diagnósticas ou terapêuticas, salvo em caso de iminente perigo de vida.

Art. 57 - Deixar de utilizar todos os meios disponíveis de diagnósticos e tratamento a seu alcance em favor do paciente.

Percebe-se, pois, à luz da regulação técnica acima transcrita, que a entidade competente para regular a atuação médica, inclusive o seu atuar ético, obriga o médico a proceder ao tratamento clínico - inclusive transfusão de sangue - necessário para salvar a vida do paciente.

Necessário advertir que os Conselhos Federal e Regional de Medicina, a exemplo de outros Conselhos Profissionais, têm previsão constitucional (artigos $5^{\circ}$, inciso XIII, 21, XXIV e 22, XVI, todos da CRFB/1988), e exercem, na qualidade de autarquias, o poder disciplinar 
quanto às suas atividades e sobre seus profissionais. Por essa razão, é possível postular que o poder normativo e regulador dos Conselhos Federal e Regional de Medicina emerge da CRFB/1988.

A reforçar a posição adotada pelo Conselho Federal de Medicina e pelo Conselho Regional de Medicina do Estado do Rio de Janeiro ${ }^{11}$, que obrigam o médico a proceder à transfusão de sangue em pacientes que estejam em risco de morte, pode-se citar a regra contida no artigo 15, do Código Civil, assim redigida:

Art. 15. Ninguém pode ser constrangido a submeter-se, com risco de vida, a tratamento médico ou a intervenção cirúrgica.

Conforme se extrai da leitura do mencionado dispositivo legal, o Código Civil de 2002 conferiu efetividade ao princípio da autonomia da vontade do paciente, permitindo que participe das decisões que digam respeito aos tratamentos que lhe serão ministrados, junto com o médico, estabelecendo claramente o limite de tal conjugação de decisões: até o momento em que a vida do paciente não correr perigo de fenecer. Nesta hipótese, o legislador civil de 2002, em franca interpretação da Constituição Federal de 1988, estabeleceu que, em havendo perigo de morte do paciente, o médico, conhecedor de estudos técnicos, deve sempre atuar para impedir que tal aconteça, cabendo a ele decidir sobre as técnicas médicas disponíveis, independentemente de crenças religiosas, inclusive por parte dos médicos.

Necessário ainda registrar que o Código Civil de 2002, em franca "interpretação autêntica" da CRFB/1988, trouxe ao ordenamento jurídico duas regras de conduta sobre a autonomia da vontade e os direitos da personalidade, que merecem ser destacadas nesta dissertação: (1) aduz serem os direitos da personalidade intransmissíveis e irrenunciáveis, e que não podem sofrer limitação voluntária; e (2) que é vedado ao ser humano a disposição do próprio corpo, inclusive quando importar em permanente diminuição da integridade física. Confira-se, a propósito, as dicções dos artigos 11 e 13 do referido Código Civil:

Art. 11. Com exceção dos casos previstos em lei, os direitos da personalidade são intransmissíveis e irrenunciáveis, não podendo o seu exercício sofrer limitação voluntária.

Art. 13. Salvo por exigência médica, é defeso o ato de disposição do próprio corpo, quando importar diminuição permanente da integridade física, ou contrariar os bons costumes. Parágrafo único. $\mathrm{O}$ ato previsto neste artigo será admitido para fins de transplante, na forma estabelecida em lei especial.

11 Em razão da inexistência de regulamentação específica no Estado de Santa Catarina, a legislação de outros Estados serão utilizadas para subsidiar a pesquisa. 
Consoante as regras acima transcritas, parece que há normas jurídicas vigentes que impedem a objeção de consciência por parte de pessoas que se dizem seguidoras das Testemunhas de Jeová para recusarem transfusão de sangue e, assim, disporem do próprio corpo e também do maior direito da personalidade tutelado pela Constituição da República de 1988, qual seja, a vida.

Isto não quer dizer, porém, que os médicos não devam buscar, o quanto possível, as técnicas médicas que não contrariem as crenças religiosas dos pacientes. Devem fazê-lo até o limite em que não se verificar a encruzilhada que responde à indagação: o tratamento contrário à vontade do paciente ou a morte? Nesta hipótese, deve decidir pelo tratamento contrário à vontade do paciente para preservar o maior e primordial direito fundamental tutelado pela Constituição da República de 1988, qual seja, a vida humana. Esta, ao que parece, é a posição de Carlos Emmanuel Ragazzo, que, discorrendo sobre o problema objeto desta investigação, aduz:

\begin{abstract}
No Brasil, a doutrina entende que a recusa deve ser respeitada, desde que não haja risco de vida. A letra do art. 15 do Código Civil vem permitindo essa interpretação, o que, aliás, já era uma posição jurisprudencial mesmo antes da promulgação do novo diploma cível. A prevalência do direito à vida, considerado como verdadeiramente indisponível, sobre o direito de autodeterminação, constitui o fundamento das decisões judiciais que permitem a intervenção médica quando há risco iminente de vida (RAGAZZO, 2007, p. 114).
\end{abstract}

Deste modo, os artigos 11, 13 e 15, todos do Código Civil, e as regras técnicas dos Conselhos Federal e Regional de Medicina do Estado do Rio de Janeiro e, ainda, o Código de Ética Médica, conferiram efetividade ao maior direito fundamental protegido pela Constituição da República de 1988, cuja defesa incessante e intransigente compete ao Estado, isto é, a vida humana, sem a qual (e/ou contra ela) não há razão jurídica para se pleitear o exercício de qualquer outro direito fundamental, inclusive a liberdade religiosa.

\title{
CONCLUSÃO
}

O direito fundamental à vida e à saúde está previsto na Constituição da República de 1988 nos artigos $5^{\circ}$ e $6^{\circ}$, que estão assim redigidos:

Art. $5^{\circ}$ Todos são iguais perante a lei, sem distinção de qualquer natureza, garantindose aos brasileiros e aos estrangeiros residentes no País a inviolabilidade do direito à vida, à liberdade, à igualdade, à segurança e à propriedade, nos termos seguintes (...). Art. $6^{\circ}$ São direitos sociais a educação, a saúde, o trabalho, a moradia, o lazer, a segurança, a previdência social, a proteção à maternidade e à infância, a assistência aos desamparados, na forma desta Constituição. 
Conforme se percebe, por expressa disposição constitucional, a vida e a saúde são direitos fundamentais e sociais invioláveis do cidadão e, nos termos do artigo 196, da CRFB/1988, é dever do Estado protegê-los:

Art. 196. A saúde é direito de todos e dever do Estado, garantido mediante políticas sociais e econômicas que visem à redução do risco de doença e de outros agravos e ao acesso universal e igualitário às ações e serviços para sua promoção, proteção e recuperação.

Se assim for, e efetivamente o é, a partir da vida e do seu inafastável corolário existência humana - é que surgirão e que serão interpretados todos os outros direitos fundamentais previstos na CRFB/1988, dentre eles o direito à autonomia da vontade para professar crenças religiosas.

Não é de se estranhar que o direito fundamental à vida humana deve ser considerado um direito universal quase que absoluto, não devendo ser relativizado e/ou flexibilizado para atender a culturas regionais religiosas e/ou fundamentalistas. $\mathrm{O}$ conceito de direitos fundamentais, mormente o cunhado por estudos produzidos no ocidente, sobretudo para combater as visões da perspectiva à luz da teoria do relativismo cultural, não autoriza o discurso utilizado para garantir um direito fundamental extremado por uma interpretação religiosa e/ou cultural em detrimento da vida humana. Isto é, à luz da doutrina universalista dos direitos humanos, não é possível que cada cultura - ou ramo dela, tal qual uma religião - tenha liberdade para estabelecer tratamentos prioritários aos direitos fundamentais, segundo suas convicções, crenças e doutrinas.

Ademais, apesar de as doutrinas modernas não estabelecerem um conceito apriorístico e determinado do que seja a dignidade humana como valor a guiar a aplicação e interpretação dos direitos fundamentais, mas estabelecerem que no referido conceito está, certamente, a possibilidade de o cidadão ser responsável pelos destinos da sua existência e vida ${ }^{12}$, de maneira que tal concepção não pode ser levada ao extremo, sobretudo em um país como o Brasil, dotado de quantidade imensa de crenças e expressões religiosas, com fundamentos dos mais diversos, para permitir que pessoas, muitas das vezes influenciadas por discursos alheios, mas sem profunda convicção de sua real crença e de suas verdades, atente contra a própria vida. Por outro lado, não se pode desconsiderar que o corolário maior da dignidade humana é a vida, sem a qual, repita-se, não há que se falar ou justificar o exercício de nenhum outro direito para conferir

\footnotetext{
${ }^{12}$ Neste sentido, manifesta-se a doutrina de Ingo Wolfgang Sarlet. Dignidade da Pessoa Humana e Direitos Fundamentais na Constituição Federal de 1988. Porto Alegre: Livraria do Advogado, 2001, pp. 38-40 e 60.
} 
dignidade a um cidadão; até porque se o destinatário da proteção estiver morto, não será possível pretender proteger a dignidade humana. Na esteira do que ora se sustenta, oportuna a transcrição da doutrina dos professores da Universidade Federal de Juiz de Fora Rodrigo Iennaco de Moraes e Rodrigo Esteves Santos Pires, em artigo intitulado "Transfusão de sangue em pacientes testemunhas de Jeová: religião, ética e discurso jurídico-penal”:

\begin{abstract}
Filiamo-nos à corrente dos que vêem, como pressuposto do princípio da dignidade da pessoa humana, a intangibilidade da vida. Estabelecida essa premissa, a ocorrência de iminente perigo de vida se traduz em autorização constitucional para que o médico, independentemente da vontade do paciente (ou de quem o represente), realize a transfusão, quando cientificamente, observada a lex arte, revele-se como o único meio apto a salvar a vida em iminente perigo de perecimento. Liberdade e vida são bens jurídicos positivados constitucionalmente em nível fundamental. Porém, não se lhes empresta, num raciocínio jusnaturalista, a mesma envergadura. Isso se dá porque, embora se reconheça que sem liberdade pode não haver vida digna, sem vida não faz sentido falar-se em liberdade e não há razão para se discutir dignidade. A vida tem valor absoluto, numa escala de valores que precede a positivação ou o reconhecimento jurídico de tutela de quaisquer outros bens ou interesses. (...) Como dito, sem vida não há dignidade, nem liberdade, nem convicção, nada. E se a vida é valor absoluto, toda e qualquer conduta tendente à sua preservação encontra, iniludivelmente, esteio constitucional. (...) E sem que isso implique a negação da própria liberdade de opção pela morte. Não. Implicará, sim, o reconhecimento constitucional de outro viés da própria liberdade, qual seja, o seu e o nosso direito de intervenção, sempre que possível, em favor da vida, de sua preservação, de sua intangibilidade. Se alguém resolve se matar por convicção religiosa, utilizando-se de qualquer meio, que o faça por seus próprios meios e fora da esfera de intervenção daqueles que, também por convicção religiosa, por dever legalmente previsto, ou simplesmente por amor à vida, não se podem curvar passivamente diante de uma vida que, com a utilização dos meios terapêuticos disponíveis (e, frise-se, quando os meios aceitos pelo paciente não se mostrarem eficazes), provavelmente não se ceifaria. É a dignidade da pessoa humana - que tem na existência da vida seu pressuposto inafastável - o valor fundante de toda e qualquer interpretação constitucional dos direitos fundamentais. A dignidade da vida pressupõe a vida. Somente em atenção à vida e enquanto ela durar fará sentido a positivação da tutela de sua dignidade (MORAES \& PIRES, 2012, p. 94).
\end{abstract}

Reforça-se, com isso, a tese de que em juízo de ponderação de valores entre o exercício momentâneo de uma crença religiosa que exponha a risco o direito à vida (e de existência) do cidadão e o dever do Estado de, por meio de seus profissionais da saúde (ou mesmo de médicos privados) de garantir a inviolabilidade do direito à vida (e da existência humana, como expressão maior do princípio da dignidade da pessoa humana), deve-se, por força do disposto nos artigos $5^{\circ}$, caput, e 196, ambos da CRFB/1988, atuar em defesa da vida e da existência humana (valor fundamental universal), até porque a inação do médico, agente do estado ou não, pode representar, para ele, severas punições administrativas, civis e criminais.

Nem a liberdade de religião nem a laicidade do Estado devem impedir o Poder Público de agir em defesa da vida humana ao ter ciência de que pessoas estão colocando em risco suas próprias vidas - por fundamento religioso (ou não) - e podem vir a atingir a esfera jurídica de terceiros (como no caso dos médicos, que acabam ficando em posição de vulnerabilidade caso 
deixem de atuar). A proteção de um direito fundamental (liberdade de crença e religião) não pode esvaziar, por completo, o exercício de outro dever constitucional imposto, sobretudo, ao Estado, que é o de garantir a preservação da vida humana.

Sem dúvida, são situações difíceis que se apresentam no liame entre a liberdade de crença e a possibilidade de intervenção estatal decorrente de sua laicidade. Aparentemente, a liberdade religiosa e o desenvolvimento de seus fundamentos devem ser exercidos de modo razoável e proporcional, sobretudo para não sacrificar o maior bem jurídico, tido por fundamental e inviolável, e, por isso, protegido constitucionalmente, que é a vida e a existência humana. Do contrário, a intervenção estatal se faz necessária, até mesmo como medida de garantia da ordem pública.

Com efeito, não é razoável, à luz dos artigos 5², caput, e 196, ambos da CRFB/1988, que uma pessoa se dirija a um hospital (público ou privado) para receber tratamento médico, isto é, para buscar cura ao mal que lhe aflige, e, sob os argumentos de privacidade, autonomia da vontade e objeção de crença religiosa, imponha o não agir a um médico, impedindo-o de cumprir com sua missão maior que é a de salvar vidas, valendo-se das técnicas médicas disponíveis, bem assim expondo-o à sorte de experimentar consequências civis (com ações indenizatórias e/ou ações regressivas do Poder Público caso seja o Estado condenado pela omissão médica), administrativas perante o Conselho de Medicina respectivo e também perante as Comissões Disciplinares do Poder Público a que estiver vinculado - na hipótese de médicos servidores públicos - e criminais, caso se entendam presente delitos penais, tal como omissão de socorro. $\mathrm{O}$ meio empregado para conferir, eventualmente, efetividade ao direito fundamental à liberdade de crença religiosa pode colocar em risco o bem jurídico maior tutelado pela CRFB/1988, que é a vida. A opção da Testemunha de Jeová viola, assim, o princípio da razoabilidade, na vertente dos subprincípios da necessidade e proporcionalidade em sentido estrito.

Os Tribunais do país vêm enfrentando a questão jurídica aqui debatida com cautela e, na grande maioria dos casos, têm decidido pela licitude da conduta médica que se opõe à crença religiosa de uma pessoa para, no intuito de salvar a vida que está em iminente perigo de fenecimento, obrigar-lhe a receber transfusão de sangue.

Necessário, ainda, um último argumento em prol da licitude da conduta do médico que, na iminência de fenecimento da vida, impõe a uma pessoa, mesmo que contra a sua crença religiosa, determinado tratamento. O Código Penal Brasileiro, no artigo 146, estabelece 
claramente que tal situação de fato não constitui crime contra a liberdade individual, excluindo a antijuridicidade ou a tipicidade da conduta. Confira-se:

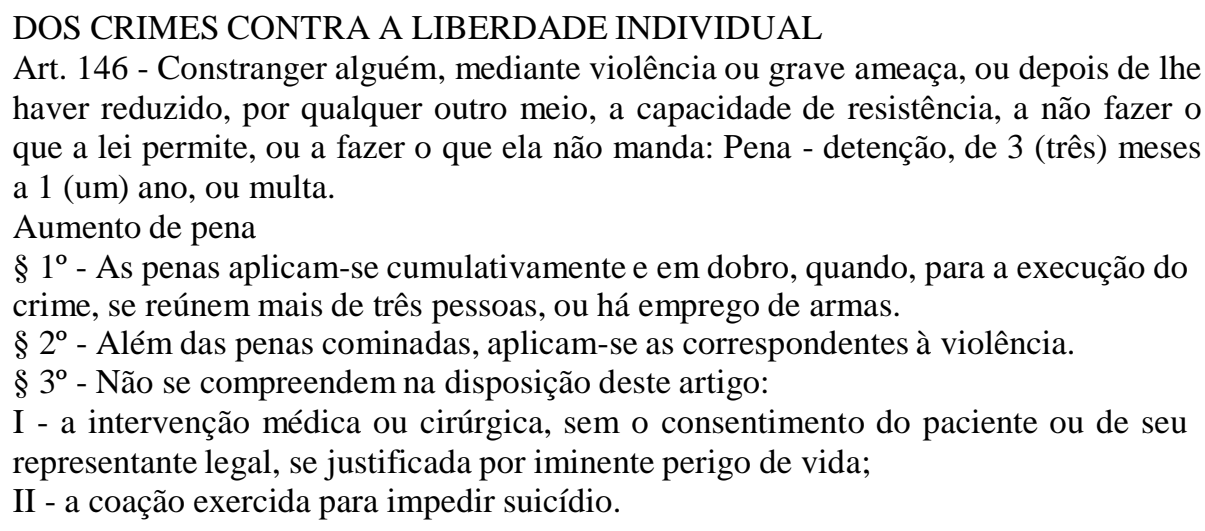

Conforme se percebe, a legislação penal brasileira propõe, ainda que implicitamente, o dever do médico de proceder à intervenção médica sempre que a vida do paciente estiver correndo perigo, o que inclui a hipótese de transfusão de sangue sem o consentimento do paciente por motivação de crença religiosa. Importa ratificar: à luz das regras constitucionais, legais e regulamentares antes mencionadas, os médicos, sobretudo aqueles que trabalhem em hospitais públicos, diante de pessoas, maiores ou menores de idade, que se dizem Testemunhas de Jeová e por isso recusam tratamento médico que envolva transfusão de sangue, devem procurar atender à manifestação de crença e religião dos pacientes, empreendendo, para tanto, todos os esforços e conhecimentos técnicos, salientando, porém, que se não houver alternativa para salvar a vida humana, deve a transfusão de sangue ser realizada, ainda que contra o consentimento do doente, ainda emitido de forma verbal e/ou escrita.

\section{REFERENCIAS}

BRASIL. Código Civil de 2002. Brasília, DF: Senado Federal, 2016.

Código Penal. Brasília, DF: Senado Federal, 2016. $\overline{\text { Federal, } 2016 .}$

Constituição: República Federativa do Brasil de 1988. Brasília, DF: Senado

Estatuto da Criança e do Adolescente. Brasília, DF: Senado Federal, 2016.

Consolidação das Leis do Trabalho. Decreto n. 5.453, de $1^{\circ}$ de maio de 1942. Diário Oficial da União, Brasília, DF: Senado Federal, 1943. 
CONSELHO FEDERAL DE MEDICINA. RESOLUÇÃO CFM No $\mathbf{N}^{\mathbf{1}} \mathbf{\mathbf { 2 4 6 }}$ /88. Institui o Código de Ética Médica. Publicado no Diário Oficial da União em 08 de janeiro de 1988.

CONSELHO REGIONAL DE MEDICINA DO ESTADO DO RIO DE JANEIRO. RESOLUÇÃO CREMERJ no 136/1999. Dispõe sobre a postura do médico diante da recusa de paciente em receber transfusão de sangue e/ou seus derivados e revoga as disposições em contrário, especialmente o Parecer CREMERJ n. 25/94. Publicada no Diário Oficial do Estado do Rio de Janeiro em 19/02/1999.

MORAES, Rodrigo Iennacco; PIRES, Rodrigo Esteves Santos. Transfusão de sangue em pacientes Testemunhas de Jeová: religião, ética e discurso jurídico-penal. In: Revista Jurídica Unijus, v. 8, n. ${ }^{\circ} 8,2012$.

RAGAZZO, Carlos Emmanuel Joppert. O dever de informar dos médicos e o consentimento informado. $1^{\text {a }}$ Ed. (ano 2006), $2^{\text {a }}$ tir. Curitiba: Juruá Editora, 2007.

SARLET, Ingo Wolfgang. Dignidade da Pessoa Humana e Direitos Fundamentais na Constituição Federal de 1988. Porto Alegre: Livraria do Advogado, 2001. 